\title{
E-GOVERNMENT IN OPTIMIZING NON-TAX REVENUE OF THE MINING SECTOR IN INDONESIA
}

\begin{abstract}
This research purpose to analyze the strategic and technical to encourage the potential of Regional Contribution of Non-Tax State Revenues (PNBP) of the mining sector is still not optimal in Indonesia given the existing number of inhibiting factors, such as corruption loophole, non-compliance, and inefficiency throughout the mining cycle. Whereas, several demands have raised by the community in mining governance, such as better government services, the need for flexibility and accuracy in formulating policies, and the need for improving the information technology of the PNBP management system. Based on the literature review using centralization and decentralization theory, two conclusions are produced. First, PNBP governance in the mining sector has not implemented e-government in integrating the central government, regional/local governments, Mining Business Permit holders, and competence stakeholders. Second, the e-government implementation should reflect public participation, transparency, and accountability at every stage of mining activities in overcoming the supervision weaknesses and the existing regulatory gaps that have caused the non-optimal of $P N B P$ of the mining sector.
\end{abstract}

Abstrak: Penelitian ini bertujuan untuk menganalisis strategi dan teknis untuk mendorong potensi Kontribusi Daerah Pendapatan Negara Bukan Pajak (PNBP) sektor pertambangan masih belum optimal di Indonesia mengingat banyaknya faktor penghambat yang ada, seperti celah korupsi, non- kepatuhan, dan inefisiensi sepanjang siklus penambangan. Padahal, beberapa tuntutan masyarakat dalam tata kelola pertambangan, seperti pelayanan pemerintah yang lebih baik, perlunya fleksibilitas dan ketepatan dalam perumusan kebijakan, serta perlunya peningkatan teknologi informasi sistem pengelolaan PNBP. Berdasarkan tinjauan pustaka dengan menggunakan teori sentralisasi dan desentralisasi, dihasilkan dua kesimpulan. Pertama, tata kelola PNBP di sektor pertambangan belum menerapkan e-government dalam mengintegrasikan pemerintah pusat, pemerintah daerah / daerah, pemegang Izin Usaha Pertambangan, dan pemangku kepentingan yang kompeten. Kedua, implementasi e-government harus mencerminkan partisipasi publik, transparansi, dan akuntabilitas di setiap tahapan kegiatan pertambangan dalam mengatasi kelemahan pengawasan dan kesenjangan regulasi yang ada yang menyebabkan PNBP sektor pertambangan tidak optimal.

\section{Rintis Nanda Pramugar ${ }^{1}$ and Reny Y. Sinaga ${ }^{2}$}

${ }^{1}$ Staff of the Ministry of Energy and Mineral Resources and Student of Law Doctoral Program of the Diponegoro University, Semarang, Indonesia.

${ }^{2}$ Staff of the Financial, Revenue and Asset Management Agency of the Central Tapanuli Regency Government, Pandan, North Sumatera, Indonesia

yyg_rintis@yahoo.com

Keywords: e-government, nontax revenue, mining sector.

Kata Kunci: e-government, penerimaan bukan pajak, sektor pertambangan. 


\section{Introduction}

Non-Tax State Revenues (PNBP) as a supporting element of the State Budget (APBN) have fluctuated but are still in a positive corridor since the enactment of Law Number 20 of 1997 concerning Non-Tax State Revenues as amended by Law Number 9 of 2018. One of supporting PNBP in Indonesia comes from Minerba / Mining (Minerals and Coal) which always contributes to an increase in non-tax state revenue. The realization of Indonesian PNBP and Mining PNBP can be seen in the following table (Indonesia, 2003-2018):

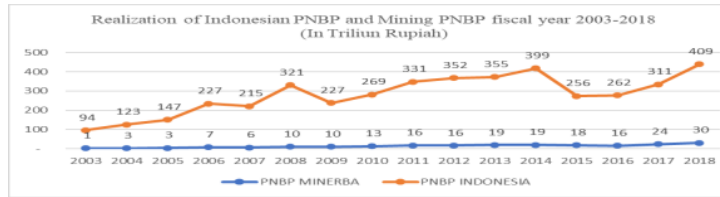

Source:

Although Mining PNBP always provides increased state revenue, it currently faces huge challenges given the results of discussions and research by The World Bank and the Ministry of Finance of the Republic of Indonesia which found that the cause of the low amount of Indonesian state revenue from the mining sector cannot be separated from the still presence loopholes of leakage, non-compliance, and inefficiency (Pramugar et al., 2020), the rise of public demand for better government services, the need for flexibility and accuracy in formulating policies in the PNBP field and the need for development and improvement of internetbased PNBP management systems and information and communication technology (ICT). The use of the internet and ICT has greatly reduced the cost of collecting, distributing, and accessing information in government as it appears that its manifestations in the form of using egovernment tend to aim for greater access to information and to promote the goals of transparency, accountability, and also offer ways to integrate direct community involvement and participation (Bertot, Jaeger \& Grimes, 2012).

The existence of the internet and the latest information system as an eGovernment system should be adopted by every government agency in operating and providing better services to the public (Santa, MacDonald \& Ferrer, 2019) including government agencies related to the mining sector to deal with leaks and noncompliance in Mining PNBP management. Therefore, in this study there are two problem formulations that need to be answered. First, how is the implementation of e-government in managing the mining sector PNBP in Indonesia today? Second, what is the ideal way for e-government to overcome the weaknesses of oversight and regulatory gaps that lead to the nonoptimization of the mining sector PNBP?

\section{Literature Review}

The use of ICT to facilitate interaction between public authorities, citizens/individuals, businesses, or organizations in the form of e-government is needed in the management of PNBP in Indonesia given that there are so many problems and reports that must be very selective to be handled by the government (Reitz, 2006). Furthermore, the Idea of Wirtz and Daiser (2017) which states that although the definition of e-government has been directed towards the same point, that is, which sees e-government as digitizing the existing bureaucratic process and as a tool for providing information and services to citizens who closely with participation, development and democratic mechanisms, but e-government must also be seen as a transformation of the e-business model to the public sector and in terms of how the government operates based on the minimum and maximum range in 3 (three) scopes, that are the scope, subject, and technology. The scope of e-government is in the minimum range of information and service delivery while the maximum range is in the enabler for e-democracy, while the minimum range of e-government subjects is citizen while the 
maximum range is all public sector position, while decentralization as a transfer stakeholders, and the minimum range of of functions from a superior position to a technology e-government is a computer and lower position, so that centralization and web presence while the maximum range is decentralization are always relative to the the internet.

Even though one important aspect of egovernment is its potential to improve democratic governance, in certain cases it is still necessary to discuss the issue of setting reasonable limits for governmental electronic control authorities (Reitz, 2006). That is, considering the definition of e-government which is 'the process of public administration innovation to achieve innovative forms of governance and governance through the use of ICT' (Savoldelli, Codagnone \& Misuraca, 2014), it is necessary to analyze the evolution of technology use in the direction of "hybridism", as Rivera (1982) argues that hybridism in technology is a form of collaboration between a centralized system and decentralization. So it is possible for the two movements to occur simultaneously, where some functions can be transferred to a superior level of hierarchy while others are transferred to a lower level, considering that organizational or group structure in which they occur.

Webber suggested that centralization is the main principle in the country with the person who to be responsible, direction, command and source of power (Mardiasmo, 2002). Kelsen (2006) also argues that centralization is a state in a country where the policy making process and its implementation take place at the top of the hierarchy in the state (government), as the full citation states that "the conception of a centralized legal order implies that all its norms are valid throughout the whole territory over which it extends; this means that all its norms have the same territorial sphere of validity". In addition to an understanding of centralization, Kelsen (2006) also argues that decentralization is a condition in a country where the process of policy making and its implementation takes the occurrence of centralization and hierarchy in the central government), as the decentralization cannot be separated from the full affirmation states that "consists of norms function of the way business, society, that have different territorial spheres of groups, or countries that are organizationally validity" and "the statement that the state is typical in a hierarchical sense from the point decentralized or that the territory of the state of decision making during the decision is divided into territorial sub divisions means making process. that the nasional legal order contains not

Then, in order to improve democratic only centra but also local norm". Maddick governance and electronic management (1963) interpreted decentralization as "the authority run by the government realized in legal conferring of powers to discharge the management of Mining PNBP which specified or residual functions upon formally currently has many shortcomings in constituted local authorities", later Indonesia so as to make money coming into Rondinelli, Nellis dan Cheema (1983) the state treasury not optimal, it is necessary explain the decentralization is a "the creation to dissect the existing problems by using the or strengthening -financially or legally- of limitation of the theory of centralization and sub national units of goverment, the decentralization theory in applying e- activities of which are substantially outside government in the mining sector. There are the direct control of central government". several thoughts about centralization and The relation between centralization and decentralization in terms of policy decisions decentralization is implied on the principle of made and carried out directly by the leaders autonomy which, according to Law Number who are elements in the center of 23 of 2014 confirms that decentralization has government, institutions that work for implications in the form of autonomy for the national interests whose national jurisdiction, administration of government in the local and in national applicable law. Rivera (1982) community level, which means that's defines centralization as the transfer of decentralization can not take place without functions from a sub-position to a superior centralization. 


\section{Research Method}

This descriptive study uses an interdisciplinary approach in answering the formulation of existing problems, that is the linkage of economic law with social science and technology. Considering the purpose of this research is to get suggestions in overcoming the problems raised in the research (prescriptive) and to assess the programs that are run (evaluative) (Soekanto, 2010), this research will use secondary data (library research) obtained of the three legal materials, which is primary material (which is legal material that is authoritative means to have authority, such as the 1945 Constitution of the Republic of Indonesia (1945 Constitution) and related laws and regulations), secondary (which is legal material that provides an explanation of primary legal materials, such as textbooks, opinions of legal experts, articles, seminar results, research results, financial reports, examination reports), and tertiary (which are materials that can provide instructions or explanations for primary and secondary materials such as dictionaries, encyclopedias, and internet sources from appropriate and adequate pages) (Marzuki, 2008 ).

\section{Discussion}

\section{Management of Mining PNBP in Indonesia}

One way to realize the management of PNBP Mining for the prosperity of the people in accordance with the mandate of the Indonesian constitution is by optimizing PNBP Mining for Minerals and Coal. Article 1 number 1 of Law Number 9 of 2018 concerning Non-Tax State Revenue (UU PNBP) which has defined PNBP as a levy paid by individuals or entities by obtaining direct or indirect benefits for services or utilization of resources and rights obtained the state based on statutory regulations, which became the recipient of the Central Government outside of tax and grant revenues and managed in the APBN mechanism, apparently has not been as large as possible for the prosperity of the people given the massive exploitation of resources without regard to the rights of the people to live sustainably (Trihastuti, 2013) and the state itself has not received the maximum income from the acquisition of PNBP.

PNBP is managed in the APBN system, which starts from the planning, implementation, accountability stages until the supervision stage so that in these management stages there are problems that require different handling at each of these stages (Pramugar et al., 2020). Several attempts have been made by the government, in this case, the Ministry of Energy and Mineral Resources (ESDM), through several technological innovations that reflect ongoing efforts to provide excellent services and the supervision efforts inherent in the mining sector have been carried out by the Ministry of Energy and Mineral Resources, such as "MINERBA ONLINE MONITORING SYSTEM", "MODI Dashboard", Minerba License Application, "ePNBP Minerba", and "MINERBA ONE MAP INDONESIA" (Pramugar et al., 2020). But in reality, the application is still limited to reaching a minimum range of scope, subject, and technology of e-government, each of which is only limited to information and service delivery of certain citizens based on computer and web presence devices. The application has not been able to identify risks that exist in PNBP in the mining sector, such as access to public participation, transparency, and accountability in terms of criteria for granting mining permits and others issued by the Governor (which is often not announced), submission of mining licenses controlled by the beneficial owner non-transparent, proof and validity of due diligence submitted by mining permit holders regarding their capacity, financial resources and integrity (such as past behavior and compliance with law) (Pramugar et al., 2020). Even in the current mining practice, there is not yet one mining map that should be made jointly by local governments (provincial and district), the Ministry of Environment and Forestry, and the Ministry of Energy and Mineral Resources (Pramugar 
et al., 2020). In fact, Article 140 of Law No. and democratization of government 4 of 2009 concerning Mineral and Coa administration. However, the inadequacy of Mining has stipulated that the Minister of e-government in the mining sector has made ESDM oversees the administration, the Ministry of Energy and Mineral operations, apparatus resources, and Resources never be able to directly calculate governance of the implementation of mining the amount of production, the number of business management carried out by the shipments and sales as well as the calculation provincial government and district of the quality of production of mining government and oversees the implementation products directly and in real terms. What of mining business activities carried out by happens is that only reporting is done by the IUP holders, People's Mining Permit (IPR), IUP holder in one direction.

or Special Mining Business License (IUP) Ideal E-Government of mining activities according to their authority. Then in Article Although the Ministry of Energy and 142 of Law No. 4 of 2009 has been regulated Mineral Resources has made several regarding the obligation of governors and applications, but it must be realized that eregents/mayors to report the implementation government is more than just a web site, of mining businesses in their respective because some important existence of eterritories at least once every six months to government is trying to connect the the Minister of Energy and Mineral government with its citizens on a very close Resources.

Of course, the management and supervision of e-government in the mining sector must be carried out by the Ministry of Energy and Mineral Resources considering that egovernment helps the government achieve several important goals through quality websites, helps in decentralizing public administration (Prybutok, Zhang, \& Ryan, 2008), and improving the ability of the Ministry of Energy and Mineral Resources in supervising the main activities that have been carried out by local governments in the mining sector. Decentralization of public administration provided by the Ministry of Energy and Mineral Resources to local governments shows that in certain cases the central government also does not ignore the existence of local laws, which tolerate the creation of a diversity of policies that are in accordance with the character of the community. Decision making is carried out by elements outside the top of the country, although it must be carried out by the local government itself, the recipient of a mining business permit must remain responsible for local laws in force in the area where the scale, potentially simplifying government processes, stimulating internal change, and restructuring the government in terms of benefits in the form of cost savings, improved communication and coordination, increased citizen participation and increased government accountability (Koh et al., 2006).

E-government that must be implemented must be in line with several mining management principles as regulated in Article 2 of Law no. 4 of 2009, which is participatory, transparency, and accountability. The transparency through ICT becomes a very urgent need in connection with its potential in creating new opportunities for participation and accountability and making it used to support e-government and open government initiatives. This is summarized from the thought of Harrison and Sayogo (2014) which states that although there is a record which states that there are relationships that are often weak, disturbed, incomplete, or difficult to extract and explain between fiscal transparency, participation, and accountability (as the argument is based on mining exists. The rationale for transparency which is more easily achieved decentralization and regional government is a than participation and the achievement of means of implementing regional autonomy participation does not guarantee the 
achievement of accountability), but the incentives and sanctions to ensure effective conceptual interdependence between impacts. The scope of these transparency and transparency, participation and accountability initiatives can be carried out accountability is an integral requirement for on licensing, exploration, contracting, open government, where the key to creating extraction, as well as increasing revenue and effective transparency is the need to consider allocation of natural resource revenues, and a skilled audience, capable of gathering on actors related to the mining sector, information given, and then implemented in including governments, corporations, nona comprehensive and disciplined or regular governmental organizations (NGOs), media, transparency practice that is accompanied by and civil society (Acosta, 2013).

an audit, and directed at a wide audience. Furthermore, in connection with Citizen involvement in policy making is a decentralization which is the process of core element of good governance, bearing in spreading power or authority to make and mind that citizen involvement in helping and decide on policies and implement policies organizing agendas, proposing policies, and outside the top of the state hierarchy or in all forming dialogue will enhance perceptions of corners of the country, however, there is a legitimacy and fairness and foster a capacity mandate of Article 33 paragraph (3) of the for fair and informed deliberation (Harrison 1945 Constitution and Article 1 number (1) \& Sayogo, 2014). Of course, these citizen's of the PNBP Law which requires that involvement constitute an important effort to mineral resources in Indonesia can be used apply the principle of checks and balances as much as possible for the prosperity of all considering the nature of the holders of the people of Indonesia, the centralization of authority who tend to neglect the rights of supervision conducted by the Ministry of the citizens by expanding, prolonging, and Energy and Mineral Resources must be abusing their power (Priyambudi et al., proportional, fair, democratic and in 2020). accordance with the potential, conditions and

Furthermore, bearing in mind that needs of the region by involving eevery action and action must be able to government that scope, subject, and the illustrate the concept of a legal obligation to technology is in the maximum range, as a "everyone" who is considered legally brief description is described in the following competent to take responsibility for his matrix.

actions or actions (Sinaga, 2019), then the principle of transparency, participation, and accountability must be the basis in creating a maximum range of e-government in the mining sector.

The matter of transparency and accountability initiatives in the mining industry sector was also emphasized by Acosta (2013) by stating that as an effort to design a government institutional mechanism responsible for the extraction and allocation and use of revenues in reducing socioeconomic and inequality among citizens, the collection is needed, better reporting and analysis of data, and a stronger focus on the allocation and use of government spending derived from natural resource wealth, and a better understanding of the importance of 


\begin{tabular}{|c|c|c|c|}
\hline Maximum Reach & $\begin{array}{c}\text { Participato } \\
\text { ry }\end{array}$ & $\begin{array}{c}\text { Transparen } \\
\text { cy }\end{array}$ & $\begin{array}{c}\text { Accountabi } \\
\text { lity }\end{array}$ \\
\hline $\begin{array}{l}\text { Enabler for e- } \\
\text { democracy }\end{array}$ & $\mathrm{X}, \mathrm{X}, \mathrm{X}$ & $\mathrm{X}, \mathrm{X}, \mathrm{X}$ & $\mathrm{X}, \mathrm{X}, \mathrm{X}$ \\
\hline $\begin{array}{l}\text { All public sector } \\
\text { stakeholders } \\
\text { Central } \\
\text { Government/Minis } \\
\text { try of Energy and } \\
\text { Mineral Resources }\end{array}$ & $\mathrm{X}, \mathrm{X}, \mathrm{X}$ & $\mathrm{X}, \mathrm{X}, \mathrm{X}$ & $\mathrm{X}, \mathrm{X}, \mathrm{X}$ \\
\hline $\begin{array}{l}\text { All public sector } \\
\text { stakeholders } \\
\text { Regional } \\
\text { government }\end{array}$ & $\mathrm{X}, \mathrm{X}, \mathrm{X}$ & $\mathrm{X}, \mathrm{X}, \mathrm{X}$ & $\mathrm{X}, \mathrm{X}, \mathrm{X}$ \\
\hline $\begin{array}{l}\text { All public sector } \\
\text { stakeholders } \\
\text { Mining Business } \\
\text { Permit Holder }\end{array}$ & $\mathrm{X}, \mathrm{X}, \mathrm{X}$ & $\mathrm{X}, \mathrm{X}, \mathrm{X}$ & $\mathrm{X}, \mathrm{X}, \mathrm{X}$ \\
\hline $\begin{array}{l}\text { All public sector } \\
\text { stakeholders } \\
\text { Societies }\end{array}$ & $\mathrm{X}, \mathrm{X}, \mathrm{X}$ & $\mathrm{X}, \mathrm{X}, \mathrm{X}$ & $\mathrm{X}, \mathrm{X}, \mathrm{X}$ \\
\hline $\begin{array}{l}\text { All public sector } \\
\text { stakeholders } \\
\text { NGOs }\end{array}$ & $\mathrm{X}, \mathrm{X}, \mathrm{X}$ & $\mathrm{X}, \mathrm{X}, \mathrm{X}$ & $\mathrm{X}, \mathrm{X}, \mathrm{X}$ \\
\hline Internet & $\mathrm{X}, \mathrm{X}, \mathrm{X}$ & $\mathrm{X}, \mathrm{X}, \mathrm{X}$ & $\mathrm{X}, \mathrm{X}, \mathrm{X}$ \\
\hline
\end{tabular}

\section{Conclusions}

This study produces two conclusions. First, the implementation of e-government in the management of the mining sector PNBP in Indonesia is currently still limited to applications and web sites, even though there are overlaps in mining permit authority between the central government and regional governments (provincial and district level). Of course, the current management of Mining PNBP cannot be said to have implemented egovernment, especially the lack of integration of checks and balances between stakeholders, both the central government, regional governments, IUP holders, and the community. Second, the implementation of egovernment must be carried out in a broad scope of checks and balances doctrine which emphasizing the principles of transparency, participation, and accountability so that it can optimize Mining PNBP and improve the quality of regulations and supervision. It is recommended that an empirical study of the appropriate elements in the matrix proposed by the author can be carried out in subsequent studies. 


\section{References}

Acosta, A.M. 2013. The Impact and Effectiveness of Accountability and Transparency Initiatives: The Governance of Natural Resources.Reitz, J.C. 2006. E-Government, The Development Policy Review 31 (S1): American Journal of Comparative Law, s89-s105.

Bertot, J.C., Jaeger, P.T. \& Grimes, J.M. 2012. Promoting transparency and accountability through ICTs, social media, and collaborative e-government.Rivera, E. 1982. Centralization or Transforming Government: People, Decentralization of Technology Process and Policy 6(1): 78-91. Information Future Cooperation or Harrison, T.M. \& Sayogo, D.S. 2014. Competition?, Technology in Society Transparency, participation, and 4(2): 101-108. accountability practices in openRondinelli, D.A., Nellis, J.R. \& Cheema, G.S. government: A comparative study. 1983. Decentralization In Developing Government Information Quarterly Countries. Washington: The 31(4): 513-525.

Indonesia, 2005-2017. Laporan Keuangan And Development/The World Bank. Pemerintah Pusat TA.2005 s.d. 2017.Santa, R., MacDonald, J.B. \& Ferrer, M. 2019. Jakarta.

Kelsen, H. 2006. General Theory Of Law and State. New Brunswick and London: Transaction Publishers.

Koh, C.E., Prybutok, V.R., Ryan, S. \& Ibragimova, B. 2006. The importance ofSoekanto, S. 2010. Pengantar Penelitian strategic readiness in an emerging egovernment environment. Business The role of trust in e-Government effectiveness, operational effectiveness and user satisfaction: Lessons from Saudi Arabia in e-G2B. Government Information Quarterly 36(1): 39-50.

Hukum. Jakarta : Penerbit Universitas Indonesia.

Process Management Journal 12(1): 22-Wirtz, B. W. \& Daiser, P. 2017. E33.

Maddick, H. 1963. Democracy, Decentralization And Development. Bombay: Asia Publishing House.

Mardiasmo 2002. Otonomi dan Manajemen Keuangan Daerah. Yogyakarta: Andi.

Marzuki, P.M. 2008. Penelitian Hukum. Jakarta : Prenada Media Group.

Pramugar R.N, Hidayat A., Syakhroza, A. \& Sinaga, B.R.P. 2020. Supervision Reconstruction of the Ministry of Energy and Mineral Resources in Corruption Prevention of Indonesia's Mining Sectors. Test Engineering andSinaga, Management 83(March-April 2020): 12017-12030.

Priyambudi, Arief, B.N., Putera, N.S.J., Sularto, R.B. \& Sinaga, H.D.P. 2020. Political Corruption and the Role of Public Prosecutors in Indonesia. Test Engineering and Management 83(March-April 2020): 11981-11992.

\section{Government: Strategy Process} Instruments. Textbook for the Digital Society. 2nd edition, Speyer. Online available

at http://www.unispeyer.de/files/de/Lehrstü hle/Wirtz/WirtzDaiser_2017_E-

Government.pdf, p. 7-8.

Savoldelli, A., Codagnone, C., \& Misuraca, G. 2014. Understanding the e-government paradox: Learning from literature and practice on barriers to adoption. Government Information Quarterly 31(S1): S63-S71.

H.D.P. 2019. Pengaturan Pertanggungjawaban Mutlak Wajib Pajak di Indonesia dalam Perspektif Keadilan dan Kemanfaatan Umum. Jurnal Hukum Pembangunan 49(3): 517-546. 
Journal Accounting and Finance

Edisi Vol. 5 No. 1 Maret 2021

Universitas Telkom

Trihastuti, N. 2013. Hukum Kontrak Karya

Pola Kerjasama Pengusahaan

Pertambangan di Indonesia. Malang :

Setara Press. 